\title{
Stock Valuation Analysis of Islamic Banks in Related to Forming Holding
}

\author{
Anton Adventus Kacaribu \\ Universitas Pelita Harapan \\ anton.kacaribu@lecturer.uph.edu
}

\begin{abstract}
This study aims to estimate the fair value of equity per share and to analyze undervalued or overvalued value of the company PT Bank BRI Syariah Tbk. Result on this study combine market approach, book value approach and discount of future cash flow approach, so it can deliver comprehensive result. On the other side, this study or valuation specialize on financial industry due to uniqueness and complexity of the industry. PT Bank BRI Syariah Tbk was chosen, because of the plan of the Ministry of State-Owned Enterprises of the Republic of Indonesia to merge 3 Sharia Banks, PT Bank BRI Syariah Tbk, PT Bank Syariah Mandiri and PT Bank BNI Syariah. Only, PT Bank BRI Syariah is public company. This research is a descriptive analysis, the data and information used are secondary data from PT Bank BRI Syariah Tbk through its annual reports, while other data used come from data and reports from other supporting institutions. This study uses three methods to value the share, Free Cash Flow to Equity, Relative Valuation and Abnormal Earning. The conclusion is, fair value of PT Bank BRI Syariah is IDR 482.47 so, the value is undervalued.
\end{abstract}

Keywords: Stock Valuation, Free Cash Flow to Equity, Relative Valuation, Abnormal Earning, Sharia Bank Merger

\begin{abstract}
Abstrak
Penelitian ini bertujuan untuk mengestimasi nilai wajar per lembar saham dan untuk menganalisa apakah nilai PT Bank BRI Syariah Tbk berada pada posisi undervalue atau overvalue. Hasil penelitian ini mengkombinasikan pendekatan pasar, pendekatan nilai buku dan arus kas masa depan yang didiskonto, sehingga hasil dari penelitan ini menjadi komprehensif. Disisi lain, penelitian ini mengkhususkan pada penilaian industri keuangan dikarenakan keunikan dan kompleksitas dari industri keuangan itu sendiri. Dipilihnya PT Bank BRI Syariah sebagai objek penilaian, dikarenakan rencana holding dari Kementerian Badan Usaha Milik Negara untuk menggabungkan 3 Bank Syariah Nasional, yaitu PT Bank BRI Syariah Tbk, PT Bank Syariah Mandiri dan PT Bank BNI Syariah. PT Bank BRI Syariah merupakan satu-satunya dari ketiga bank tersebut terdaftar di Bursa Efek Indonesia. Penelitian ini menggunakan metode analisis deskriptif, serta data dan informasi yang digunakan merupakan data sekunder yang diambil dari Laporan Keuangan Tahunan PT Bank Rakyat Indonesia Tbk, dan data sekunder lainnya diambil dari institusi lainnya yang mendukung. Penelitian ini menggunakan tiga metode, yaitu Arus Kas Bersih ke Ekuitas, Relative Valuation, dan Abnormal Earning. Hasil penelitian ini memperlihatkan nilai wajar per lembar saham PT Bank BRI Syariah Tbk sebesar Rp482,47, dimana hal ini menunjukkan nilai per lembar sahamnya undervalue.
\end{abstract}

Kata kunci: Penilaian Saham, Arus Kas Bersih ke Ekuitas, Relative Valuation, Abnormal Earning, Merger Bank Syariah

\section{Cara Mengutip:}

Kacaribu, A. A. (2020). Stock Valuation Analysis of Islamic Banks in Related to Forming Holding. Esensi: Jurnal Bisnis dan Manajemen, 10(2): 205-214. DOI: https://doi.org/10.15408/ess.v10i2.18857 


\section{INTRODUCTION}

The forming Merging, Shariah Bank State-Owned Enterprises, is a strategic masterplan from the State-Owned Enterprises Minister to develop efficiency, synergy, and increase value-added State-Owned Enterprises in Banking and Financial Service Sector. This syariah bank merger is intended to open up wider funding options in Indonesia. This merger will be carried out in the first quarter of 2021.

The Merging process is really interesting and unique because, in the merging process Shariahs Banking, PT Bank BRISyariah (Tbk), PT Bank Syariah Mandiri Tbk and PT Bank BNI Syariah are involved, but only PT Bank Syariah that has been listed on Indonesian Stock Exchange (IDX). Because only one of the Islamic banks has become a public company and is listed on the stock exchange, namely PT Bank BRISyariah (BRIS), it is possible that BRIS will become the leader new entity of this combined Syariah /Islamic bank.

However, if we look at the amount of total assets and total equity, it could be that Bank Syariah Mandiri as the leader which has the largest total assets and total equity becomes this combined Islamic bank entity. The following is presented total asset and equity of each sharia bank on table 1.

Table 1. Total of Asset and Equity of Sharia Banks

\begin{tabular}{lcc}
\hline \multicolumn{1}{c}{ Company } & Total Asset (Q1 2020) & Total Equity (Q1 2020) \\
\hline PT Bank Syariah Mandiri & IDR 114 trillion & IDR 9,61 trillion \\
PT Bank BNI Syariah & IDR 51 trillion & IDR 5,18 trillion \\
PT Bank Rakyat Indonesia Syariah Tbk & IDR 42 trillion & IDR 5,16 trillion \\
\hline \multicolumn{1}{c}{ Total } & IDR 207 trillion & IDR 19,95 trillion \\
\hline
\end{tabular}

This study only focuses on the fair Value share of BRIS, because only PT BRI Syariah Bank has been listed on the Stock Exchange. The Market Value BRIS shares Price began to rise, especially after Indonesia Stated Owned Enterprises Minister Erick Thohir conveyed his plan on the first week July 2020, to make Islamic banks bigger and stronger through the merger of Syariah Islamic banks.

This study aims to determine the fair value of BRIS shares. Valuation means the process by the respective valuation subject to allocate of a object into value, in most cases in form of a monetary value.(Matschke et al., 2010), which means by conducted valuation process valuer can determine the current worth of an asset or a company. Valuer analysist uses vary techniques to determine value of company by looks at the company's management, the composition of its capital structure, the prospect of future earnings and market value of assets $^{\left({ }^{(C h e n, 2020 .)}\right.}$ Besides, for purpose of merger, valuation is useful for investor to do investment. Investment is the placement of the funds at this time hoping to generate profits in the future. Investors in making decisions need important information as the base for determining investment choices. Investment decision is very important because to obtain the optimum return and avoid losses.(Fachrudin \& Fachrudin, 2016).

Fair value or intrinsic value is the value of discounted a series of cash inflows that will be generated in the future(Lestari Puji Astuti, 2013). The approach used to determine 
intrinsic value, based on discounted cash inflows, is in the form of Free Cash Flow to Equity. The concept of this approach is based on the reason that ownership of an asset by an investor is more than just to own it. Investors expect future returns in the form of cash inflows (Kruschwitz \& Löffler, 2013)particularly for those in finance. The literature on firm valuation recommends logical, quantitative methods, which deal with establishing today's value of future free cash flows. In this respect firm valuation is identical with the calculation of the discounted cash flow, DCF. There are, however, different coexistent versions, which seem to compete against each other. Entity approach and equity approach are thus differentiated. Acronyms are often used, such as APV (adjusted present value

The calculation of the valuation based on relative market value on the transaction value of companies that have similar businesses using the relative value between those to be assessed with similar companies in the market using market multiples transaction (Johan \& Herbani, 2018). Declerck (2016) conducted research focused on the market multiplies of sales by comparing the performance of financial statements and this method of relative market multiples has been widely used in negotiations between buyers and sellers.

Valuation using Abnormal earnings conducted by Dawar (2014)namely, abnormal earnings, book value, accruals and cash flows over a period of time and their valuation relevance in Indian scenario. Design/methodology/approach - The study utilizes the generalized version of the Ohlson model which links market prices with abnormal earnings, book value and earning components (accruals and cash flows, determining a company's equity value based on both its book value and its earnings. Contributes in filling the gap in the literature in Indian scenario using a set of Indian listed companies by examining the persistence ability of accounting variables, namely abnormal earnings, book value, accruals and cash flows over a period of time and their valuation relevance companies. The Abnormal Earning Model also known as residual individual income, considerate management's decisions whether will cause a company to perform better or worse than anticipated.

By using the company valuation method Free Cash Flow to Equity, Relative Valuation, and Abnormal Earning, this article proposed to estimate the fair value stock of BRIS in related to forming merger Syariah Banking as a whole by approaching the potential cash inflows that are discounted, comparison of similar companies and value current book on the company's potential profit (abnormal earnings) in the future. Thus giving investors a deep understanding of the fair value of the stock price and ultimately becomes the basis for investment considerations.

Karlsson et al., (2011) conduct research about stock price valuation, a case study in dividend discount model and free cash flow to equity model. This research using dividend discount model (DDM) and free cash flow to equity model (FCFE). The result of this research is tendency of FCFE model works better towards company with payout ratio and DDM model works better in company high dividend payout ratio.

Valuation of Shares in the Coal Mining Industry shows the results of under value to market prices (Magdalena, 2012) the valuation methods used were free cash flow to equity, abnormal earnings and relative valuation. Free Cash Flow To Equity (FCFE) Valuation Method is very appropriate to use in companies with known financial source structures such as banking (Vlaovic-Begovic et al., 2013). The advantage is in the detailed design of the balance sheet and income statement which include all future inflows and outflows of funds then the 
projected balance is largely brought to real future balances. The result of estimates based on projected cash flows contributes to more accurate and more realistic value of the company.

Research on firm value using the relative valuation conducted by Omran (2003)the price sales (PS examines stock valuation in the emerging market of the United Arab Emirates using three valuation multiples in the period from 1996-2001, the price sales (PS), the price book value (PBV) and the price earnings (PE). Abu Dhabi Islamic bank seems to be trading at higher PE and PS multiples compared with commercial banks.

Empirical evidence of A Comparative Analysis of Bank Valuation Models (Gounder \& Venkateshwarlu, 2017), suggests that the Abnormal Earning valuation (residual income model) is superior and more reliable to the relative valuation model when it comes to measuring bank shareholder value.

This study is a continuation of several previous studies which mostly focused on the valuation of manufacturing industry. The novelty of this study use FCFE that adjusted to the nature of finance industry and use Hamada equation (Munshi, 2014) to Beta Industries because mostly in finance industry composition of liabilities dominance compare to its equity. Estimating FCFE on manufacturing industry is easy, due to net capital expenditure, noncash working capital and debt ratio can be obtained from the financial statements. On finance industry, estimating FCFE is particularly difficult several reasons. For the reason is:

1. Value of capital expenditure and working capital is difficult to estimate due to asset mostly in the form of financial claims.

2. Complexity and unique of balance sheet

In the end, financial services industry can develop only up to the book value of their equity to support growth and maintain the value of the regulatory capital ratio (also known as the capital adequacy ratio) Damodaran (2009) said that in general, the book value of assets and capital becomes irrelevant for companies not in financial industry. However, in financial industry, the book value of equity is relevant for valuation. This is because the book value of financial service companies is not only historical data, but also reflects the company. As well as the value of the capital adequacy ratio, or regulatory capital ratio, is obtained based on book value. So that if the ratio is negative, of course the government or the central bank can close the company.

\section{METHOD}

This study is using three methods to able determine the fair value of equity per share. The three methods is Free Cash Flow to Equity with using Discounted Cash Flow, Relative Valuation with using Price to Earning, Price to Book Value and Price to Sales, and the last is Abnormal Earning.

\section{Free Cash Flow to Equity Method}

The free cash flow to equity means a free cash flow which is available to the holders of ordinary shares after all operational expenses of interests and principal are paid and after necessary investments in net working capital and fixed assets are achieved.(Stowe, John D., Robinson, Thomas R., Pinto, Jerald E., McLeavey, 2002) 
For using free cash flow to equity, is must to estimate using discounted cash flow, by projection is cash flow for 5 years ahead. This study is using asset base, so the projection is based on asset, and for discounted cash flow, is needed cost of equity to make discount rate and the further discount factor. For the discount rate, this study using cost of equity.

\section{Cost of Equity}

Cost of Equity is rate of return requires by investor for investing in enterprise. As generally, the formula of cost of equity can get by Capital Asset Pricing Model (CAPM). Here, is the formula:

$$
E_{(r)}=K_{e}=R_{f}+\beta\left(E R P_{m m}-C R P\right)
$$

$\mathrm{E}_{(\mathrm{r})} \quad=$ Expected return of asset

$\mathrm{K}_{\mathrm{e}} \quad=$ Cost of equity

$\mathrm{R}_{\mathrm{f}} \quad=$ Risk-free rate

$\beta=$ Beta of asset

$\mathrm{ERP}_{\mathrm{mm}}=$ Mature market equity risk premium

$\mathrm{CRP}=$ Country Risk Premium

For the value of Beta $(\beta)$, this study using unlevered beta of finance/banking sector, because the general operational enterprise using deposit from customer and debt for customer. Levered beta must be calculated. Below is formula of levered beta:

$$
B_{L}=\beta_{U}(1+(1-t) L / E)
$$

$\mathrm{B}_{\mathrm{L}} \quad=$ Beta levered

$\mathrm{B}_{\mathrm{U}} \quad=$ Beta unlevered

$\mathrm{t} \quad=$ Tax rate

$\mathrm{L} \quad=$ Book value of liabilities

$\mathrm{E} \quad=$ Book value of equity

Free Cash Flow to Equity using Discounted Cash Flow, is used in this study because to estimate net capital expenditure and noncash working capital is difficult for bank. To estimate FCFE for bank, this study is using reinvestment in regulatory capital as reinvestment. After get the reinvestment, is able to estimate and obtain current regulatory capital and current return on equity. Here, below the formula of current regulatory capital ratio and return on equity.

$$
\begin{aligned}
& \text { Current regulatory capital ratio }=\frac{\text { Regulatory Capital }}{\text { Asset Base }} \\
& \text { Current return on equity ratio }=\frac{\text { Net Income }}{\text { Regulatory Capital }}
\end{aligned}
$$

By using the ratio, it can be estimate the cash flow in the future, so that, can be applied to free cash flow to equity method.

$$
\mathrm{FCFE}_{\text {Bank }}=\text { Net Income - Increase in Regulatory Capital }
$$




\section{Perpetuity State}

Perpetuity state is state of infinite amount of time. This state is project of stabilize cash flow or constant stream of identical cash flow with no ending .Terminal value is a measure of how much the project is worth at the end of its lifetime $\mathrm{N}$ years. In a simple way, terminal value can be explain as approach of grow with a constant rate forever. With assumption of long life company based on going concern aspect, terminal value approach will be give more reasonable yield (Damodaran, 2012). The general formula used in calculating terminal value can be seen as follows

$$
\text { Terminal Value }=\frac{\mathrm{FCFE}_{\mathrm{n}+1}}{\mathrm{~g}}
$$

$\mathrm{FCFE}=$ Free cash flow to equity $\mathrm{n}$ year

g = Stable growth

\section{Determine The Value of Equity}

Value of equity is total present value of estimation of free cash flow to equity from 2019 as current year to 2024 added with present value of perpetuity value. The value of equity can be seen as.

$$
\sum_{i=1}^{t=n} \frac{\text { FCFE }}{\left[\left(1-\mathrm{K}_{e}\right)\right]^{t}}+\frac{\text { Perpetuity }}{[(1-K e)]^{t}}
$$

\section{Relative Valuation Method}

For using relative valuation method, the value of enterprise is compared to value assessed by market, by using similar comparable enterprise. To get comparable industries, this study using Standar Penilaian Indonesia 330 (SPI 330). That is:

1. Industry, business activity and product.

2. Growth in sales and earnings and capital structure.

3. Historical financial performance

4. Company size

5. Market Share

By using relative valuation methods, the study using three comparable ratios:

\section{Price to Earning Ratio}

Price to Earning Ratio is measure share price per share to per-share earning. (Damodaran, 2012)The purpose is to see capabilities of enterprise to generate income per share.

$$
\text { PER }=\frac{\text { Market Price per Share }}{\text { Earning per Share }}
$$

\section{Price to Book Value Ratio}

Price to Book Value is measure market value per share to book value per share (Damodaran, 2012).

$$
\mathrm{PBV}=\frac{\text { Market Value per Share }}{\text { Earning per Share }}
$$




\section{Price to Sales Ratio}

Price to Sales Ratio is measure market value of equity to revenue (Damodaran, 2012). The purpose is to see capabilities of enterprise to generate revenue.

$$
\mathrm{P} / \mathrm{S} \text { Ratio }=\frac{\text { Market Value of Equity }}{\text { Revenue }}
$$

\section{Abnormal Earning Method}

Abnormal earning is a valuation method to value company's equity based on book value and earnings . It can be calculated by initial book value of the year reduced by growth of the book value. The formula can be seen as follows:

$$
\text { Abnormal Earning }=\mathrm{E}-\left(\mathrm{K}_{e} \times \mathrm{BV}\right)
$$

\section{Discount for Lack of Control, Premium of Control and Discount for Lack of Marke- abilities}

The using for Discount Lack of Control, Premium of Control and Discount for Lack of Marketabilities, this study is using Peraturan VII.C.3 from Otoritas Jasa Keuangan as reference.

\section{Reconciliation of Value}

For reconciliation, the final result of valuation is reconcile the value of equity from three methods, due to appropriate and rational results, by weighted every methods.

\section{RESULTS AND DISCUSSION}

This study used three method of valuation, can be seen as below:

\section{Free Cash Flow to Equity}

The following is presented result of Free Cash Flow to Equity method on table 2.

\begin{tabular}{|c|c|}
\hline Highlights & Present Value \\
\hline FCFE 0 & $40,027,273,541$ \\
\hline FCFE 1 & $96,417,578,656$ \\
\hline FCFE 2 & $92,288,910,295$ \\
\hline FCFE 3 & $102,245,750,671$ \\
\hline FCFE 4 & $105,290,646,249$ \\
\hline FCFE 5 & $108,426,219,327$ \\
\hline TOTAL FCFE (A) & $551,696,378,740$ \\
\hline Perpetuity Value (B) & $1,027,616,077,444$ \\
\hline TOTAL A + B & $1,579,312,456,183$ \\
\hline Current Outstanding Share & $9,716,114,000$ \\
\hline Indication Value per Share & 162.55 \\
\hline Discount for Lack of Control (20\%) & 32.51 \\
\hline Discount for Lack of Marketability (20\%) & 26.01 \\
\hline Fair Value per Share & 104.03 \\
\hline
\end{tabular}

Table 2. Result of Free Cash Flow to Equity Method 
The result of fair value per share of PT Bank Rakyat Indonesia Syariah, Tbk. using Free Cash Flow to Equity method is IDR 104.03.

\section{Relative Valuation}

The following is presented result of Relative Valuation method on table 3.

Table 3. Result of Relative Valuation Method

\begin{tabular}{lrrrrr}
\hline \multicolumn{1}{c}{ Highlights } & Multiplier & \multicolumn{1}{c}{ Fundamental } & \multicolumn{1}{c}{ Indication Value } & Weighted & \multicolumn{1}{c}{ Reconcile } \\
\hline PER & 26.73 & $5,088,036,000,000$ & $1,558,869,174,160,990$ & $5.00 \%$ & $77,943,458,708,050$ \\
PBV & 306.38 & $3,374,863,000,000$ & $7,407,641,941,902$ & $5.00 \%$ & $370,382,097,095$ \\
P/S & 2.19 & $74,016,000,000$ & $1,978,665,641,638$ & $90.00 \%$ & $1,780,799,077,475$ \\
Total & 335.31 & & & & $80,094,639,882,619$ \\
Premium Control & $20.00 \%$ & & & & $16,018,927,976,524$ \\
Discount for Lack & $20.00 \%$ & & & & $19,222,713,571,829$ \\
of Marketability & & & & & $76,890,854,287,314$ \\
Fair Value of Equity & & & & & $9,716,114,000$ \\
Outstanding share & & & & & $7,913.75$ \\
\hline Fair Value per & & & & \\
Share & & & & & \\
\hline
\end{tabular}

The result of fair value per share of PT Bank Rakyat Indonesia Syariah, Tbk, using Relative Valuation method is IDR 7.913.75.

\section{Abnormal Equity}

The following is presented result of Abnormal Equity method on table 4 .

Table 4. Result of Abnormal Equity Method

\begin{tabular}{lr}
\hline \multicolumn{1}{c}{ Highlights } & \multicolumn{1}{c}{ Present Value } \\
\hline Earning (year 0) & $162,724,858,721$ \\
Earning (year 1) & $96,444,578,881$ \\
Earning (year 2) & $74,199,988,702$ \\
Earning (year 3) & $55,922,706,990$ \\
Earning (year 4) & $40,935,804,263$ \\
Earning (year 5) & $28,676,809,937$ \\
TOTAL FCFE (A) & $458,904,747,494$ \\
Perpetuity Value (B) & $305,535,299,626$ \\
TOTAL A + B & $764,440,047,119$ \\
Current Outstanding Share & $9,716,114,000$ \\
\hline Fair Value per Share & $\mathbf{7 8 . 6 8}$ \\
\hline
\end{tabular}

The result of fair value per share of PT Bank Rakyat Indonesia Syariah, Tbk, using Abnormal Equity method is IDR 78.68.

After get value of equity per share from the three methods. The next step is reconcile the three methods. The following is presented result of reconcile of three method on table 5 . 
Table 5. Reconciliation of Three Methods

\begin{tabular}{lrrr}
\hline \multicolumn{1}{c}{ Methods } & Fair Value of per share (IDR) & Weighted & Reconcile \\
\hline Free Cash Flow to & 104.03 & $47.50 \%$ & 49.41 \\
Equity & & & \\
Relative Valuation & 78.68 & $47.50 \%$ & 37.37 \\
Abnormal Earning & $7,913.75$ & $5.00 \%$ & 395.69 \\
\hline Total & $\mathbf{8 . 0 9 6 . 4 5}$ & $\mathbf{1 0 0 . 0 0 \%}$ & $\mathbf{4 8 2 . 4 7}$ \\
\hline
\end{tabular}

So, the fair value of PT Bank Rakyat Indonesia Syariah, Tbk. is IDR 482.47.

\section{CONCLUSION}

The results of fair value from using of three methods above are very comprehensive due to the three point of view, book value, market value and discounted future cash flows.

From using the three methods, the study found that PT Bank Rakyat Indonesia Syariah, Tbk. is undervalue if compared to its market value on 31 December 2019, where, there difference about $46 \%$ between fair value and market value. The result of valuation that shows fair value per share and market price per share can be seen on table 6 .

Table 6. Result of Fair Value and Market Value

\begin{tabular}{cccc}
\hline Bank/Institution & Fair Value per share & Market Price in IDX* & \% difference \\
\hline PT Bank Rakyat Indonesia Syariah, Tbk. & 482.47 & 330.00 & $46.20 \%$ \\
\hline
\end{tabular}

*the market price is shown for 31 December 2019

Difference value of Fair Value and Market Price in Stock Exchange can be a good indicator to forming holding, due to the cost to merge and perform holding of Islamic Bank Syariah not too big.

For investors, in a volatile financial condition, the holding plan of the ministry of state-owned enterprises for holding Sharia banks is the right momentum for investors to buy shares, especially at low prices where the market value of the shares is undervalued against its fair value.

\section{REFERENCES}

Chen, J. (n.d.). Valuation Definition. Retrieved July 31, 2020, from https://www.investopedia. com/terms/v/valuation.asp

Damodaran, A. (2009). Valuing Financial Service Firms. Stern Business School, New York University, New York. http://people.stern.nyu.edu/adamodar/pdfiles/papers/ finfirm09.pdf

Damodaran, A. (2012). Investment Valuation: Toolsand Techniques for Determining the Value of any Asset.Canada:John Wiley and Sons Inc. In Investment Valuation: Tools and Techniques for Determining the Value of Any Asset. 
Dawar, V. (2014). Earnings persistence and stock prices: empirical evidence from an emerging market. Journal of Financial Reporting and Accounting. https://doi.org/10.1108/jfra06-2013-0044

Declerck, F. (2016). Mergers \& acquisitions in the food business: How did the 2002 and 2008/2009 economic crises impact corporate valuation? International Journal on Food System Dynamics. https://doi.org/10.18461/ijfsd.v7i3.731

Fachrudin, K. R., \& Fachrudin, K. A. (2016). THE INFLUENCE OF EDUCATION AND EXPERIENCE TOWARD INVESTMENT DECISION WITH MODERATED BY FINANCIAL LITERACY. Polish Journal of Management Studies. https://doi.org/10.17512/pjms.2016.14.2.05

Gounder, C. G., \& Venkateshwarlu, M. (2017). Bank Valuation Models - A Comparative Analysis. Accounting and Finance Research. https://doi.org/10.5430/afr.v6n3p116

Johan, S., \& Herbani, L. (2018). METODE VALUASI MANAKAH YANG LEBIH TEPAT UNTUK MERGER DAN AKUISISI? Jurnal Muara Ilmu Ekonomi Dan Bisnis. https://doi.org/10.24912/ jmieb.v2i1.1659

Karlsson, A., Josefsson, N., \& Jönköping, U. Ö. (2011). Stock Price Valuation Title: Stock Price Valuation. https://www.diva-portal.org/smash/get/diva2:459918/FULLTEXT01.pdf

Kruschwitz, L., \& Löffler, A. (2013). Discounted Cash Flow: A Theory of the Valuation of Firms. In Discounted Cash Flow: A Theory of the Valuation of Firms. https://doi. org/10.1002/9781118673461

Lestari Puji Astuti. (2013). PENILAIAN HARGA WAJAR SAHAM PT.KIMIA FARMA (PERSERO) Tbk DAN PT. INDOFARMA (PERSERO) Tbk MENJELANG AKUISISI. MIX.

Magdalena, M. (2012). Valuasi saham pada industri tambang batubara dengan menggunakan analisis free cash flow to equity, abnormal earning, dan relative valuation. 4240543.

Matschke, M. J., Brösel, G., \& Matschke, X. (2010). Fundamentals of functional business valuation. In Journal of Business Valuation and Economic Loss Analysis. https://doi. org/10.2202/1932-9156.1097

Munshi, J. (2014). The Hamada Equation Reconsidered. SSRN Electronic Journal. https://doi. org/10.2139/ssrn.2414221

Omran, M. F. (2003). Equity valuation using multiples in the emerging market of the United Arab Emirates. Review of Middle East Economics and Finance. https://doi. org/10.1080/1475368032000158250

Stowe, John D., Robinson, Thomas R., Pinto, Jerald E., McLeavey, D. W. (2002). Analysis of Equity Investments: Valuation.

Vlaovic-Begovic, S., Momcilovic, M., \& Jovin, S. (2013). Advantages and limitations of the discounted cash flow to firm valuation. Skola Biznisa. https://doi.org/10.5937/ skolbiz1301038v 